\title{
Corporate Performance and Executive turnover
}

\author{
Su Yaya ${ }^{1, a, *}$ \\ ${ }^{1}$ School of Management, Wuhan University of Technology, Wuhan 430000, China \\ a218228@whut.edu.cn
}

Keywords: corporate performance, degree of market, executive turnover.

\begin{abstract}
With fierce competition, the proportion of executive of listed companies change is rising recently, which has attracted the attention of many scholars. According to researches of corporate governance, corporate performance is a significant indicator to evaluate the operation and management. The thesis mainly focuses on whether the decrease of corporate performance will give rise to the turnover of senior executive, besides the thesis researches whether different degrees of market will bring about different levels of relationship. Based on the effects of government intervention and market regulation to the turnover of executive, the thesis will put forward about certain suggestions.
\end{abstract}

\section{Introduction}

Executive often set corporate strategy, determine the corporate's future development direction, is the core of one corporate, thus changing the existing executive will have great influence to the corporate. After 40 years development and accumulation in the field of executive changes, Western countries have formed a systematic theory system. The study can be divided into two stages, the first stage is from 1970s to 1990s, the research is mainly focused on whether there is a relationship between the two factors and what kind of relationship it is; For the second stage, scholars have reached a consensus on the relationship between the two, they agree that the corporate performance and executive turnover have a negative correlation relationship, and based on this view, scholars starts study the relationship under different conditions .In China, the research on executive turnover starts late, but the recent wave of executive turnover has provided plenty of fodder for the research. Ma Rujing (2016) and other scholars believe that the corporate performance is negatively related to the change of senior executives, and it is based on this viewpoint to carry out in-depth research. As the reform of the economic system is the focus of China's comprehensive reform of the system at the present stage, the Chinese economy is in a critical period of transformation and upgrading. Based on the national conditions, study on different marketization process for the influence of relationship between corporate performance and executive turnover, in order to find the optimum of the external environment of market regulation, as well as the government how to better define the functions of the government, promote the reform of economic system and puts forward related suggestions.

\section{Theoretical background and hypotheses development}

Based on incentive theory, corporate with poor business performance is likely to cause executive's departure, thus incentive executive trying to improve the corporate's performance, poor performance is one of the main causes of executive turnover, and a large number of domestic studies show that there is a negative correlation between corporate performance and the change of executives. Therefore, hypothesis 1 :

H1: there is a negative correlation between corporate performance and executive turnover.

As marketization and government intervention will have an important influence on the corporate governance mechanism. The economic development in various regions of China is relatively unbalanced, with relatively high marketization degree, economic development is more prosperous, 
and the market can play the role of allocating resources more effectively. Otherwise the economic environment in the region will weaken the regulation ability of the market. And the state-owned enterprise is different from private enterprise, as "the relationship between the government and the market" is one of the important factors affecting its corporate governance, its executive turnover is not completely rely on market mechanism, but to a large extent depend on administrative orders; And state-owned enterprises mostly have different pursuit, besides economic indicators, such as stabilizing prices and reducing unemployment. All of these will reduce the sensitivity of both the performance and the executive' turnover. Therefore, hypothesis 2 and hypothesis 3 :

H2: The promotion of marketization degree can enhance the negative correlation between corporate performance and executive turnover.

H3: Due to government intervention, the negative correlation between the performance of state-owned companies and executive turnover is lower than that of non-state-owned companies.

\section{Methodology of the empirical study}

\subsection{Data sources and sample construction}

To test hypotheses, start with listed company in Chinese A stock market with non-missing values for finance and corporate governance from 2012 to 2016, representing all sectors except for financial services. Financial institutions are excluded from sample because their financial characteristics and their reporting structure differ from those non- financial companies. And the accounting and financial data are collected from the Csmar database. Ultimately, we have 5,472 observations.

\subsection{Variable definition}

ROA is selected as the main explanatory variable. And interpreted variable is executive turnover (turnover), it is encoded 1 for years in which the firm changes its executive in that year, and 0 otherwise. The reasons for executive turnover are correspond to the following dummy avriables: Marketization Index (MI) is a dummy variable that according to the data in the 2011 annual report of China's marketization index -- the market relative process in each province takes value 1 if up to top $50 \%$. Government intervention (gov) takes value 1 if it is a state-owned enterprise. As the literature emphasizes that certain firm-specific characteristics act as factors potentially driving ROA (company size, etc.) and may account for variations in performance, we consider three variables: company size, debt ratio, competition in the market (comp). Company size, the arguments made rely on factors such greater visibility and therefore greater pressure, stronger response to stakeholder demands; size is also favorable to scale economies. Company size is assumed to be positively related to its executive turnover.We measure company size as the log of the total assets. Debt ratio, its effect is explained by the power over the resources required by the firm. Debt ratio prompts the firm to give precedence to creditors, who are generally more powerful than the other stakeholders. We measure it by total liabilities divided by total assets, and measure comp by gross profit divided by main business revenue.

\subsection{Method of Analysis}

To examine how executive turnover responds to corporate performance, we estimate the following baseline regression:

$$
\begin{aligned}
& \operatorname{Pr}(\text { turnover })=a_{1}+a_{2} \text { ROA }+a_{3} \text { size }+a_{4} \text { debt }+a_{5} \text { comp }+\varepsilon \\
& \operatorname{Pr}(\text { turnover })=b_{1}+b_{2} \text { ROA }+b_{3} \text { size }+b_{4} \text { debt }+b_{5} \text { comp }+b_{6} \text { proxy } b_{7} \text { proxy*ROA }+\varepsilon
\end{aligned}
$$

\section{Empirical results}

\subsection{Descriptive statistics}

Table 1 presents the descriptive statistics of each variable. We observe that the proportion of the executive turnover from 2012 to 2016 is close to 18\%, which means that the executive changes in the corporate is relatively common, and executive turnover in 2015 is 913 times, it is the highest proportion, $21.37 \%$, which means more than one five of the corporate have experienced executive change in 2015. And moreover, in order to study the relationship between corporate performance and 
executive turnover, the variable ROA is interpreted as a four-point sorting part, and the number of changes of executives in different performance situations is statistically analyzed. If the more executive turnover because of poor performance, we can learn that the lower performance will result in the executive turnover, and the statistical results are shown in table 2.

Table 1 Descriptive statistics

\begin{tabular}{|l|l|l|l|l|}
\hline Variable & mean & Standard deviation & minimum & maximum \\
\hline turnover & 0.18 & 0.384 & 0 & 1 \\
\hline ROA & 0.0015 & 0.045 & -0.137 & 0.176 \\
\hline MI & 0.84 & 0.366 & 0 & 1 \\
\hline gov & 0.38 & 0.484 & 0 & 1 \\
\hline size & 22.11 & 1.114 & 19.93 & 25.75 \\
\hline debt & 0.427 & 0.201 & 0.045 & 0.880 \\
\hline comp & 0.280 & 0.157 & 0.010 & 0.818 \\
\hline
\end{tabular}

Table 2 The executive turnover statistics unit:times

\begin{tabular}{|l|l|l|l|}
\hline Range of variation & turnover & $\begin{array}{c}\text { state-owned companies } \\
\text { executive turnover }\end{array}$ & $\begin{array}{c}\text { the presentage of state-owned } \\
\text { companies executive turnover }\end{array}$ \\
\hline ROA $<-0.028$ & 320 & 166 & $51.88 \%$ \\
\hline$-0.028 \leqslant$ ROA $<-0.004$ & 283 & 150 & $53.00 \%$ \\
\hline$-0.004 \leqslant$ ROA $<0.025$ & 239 & 120 & $50.21 \%$ \\
\hline ROA $\geqslant 0.025$ & 254 & 109 & $42.91 \%$ \\
\hline Total & 1096 & 545 & $49.73 \%$ \\
\hline
\end{tabular}

\subsection{Regression analysis}

Table 2 presents the regression results based on equation (1) in panel data with industry and year fixed. We find that the marginal effect of the ROA is -3.34 and significant at the $5 \%$ level, which means that bad performance likely leads to the change of executive, this result confirms hypothesis 1. Specifically, firms are allocated to two groups depending on the nature of its equity to test for differential turnover rates across state-owned and non- state-owned companies. The estimation method remains identical but is applied to both samples. For the two samples, the effect of ROA is similar to that observed previously, i.e. the predictive coefficient associated with the ROA variable is negative and statistically significant. However, it can be noted that the coefficient associated with the ROA variable is about twice as high in the state-owned companies sample as it is made up of non-state-owned companies, and this validates hypothesis 3 . And then adds the market index variable, the analysis results show that there is a much stronger negative correlation between the two. At the same time, the marketization index is positively correlated with executive turnover, which means in areas with high degree of marketization, it is more likely to be affected by economic regulation, and it is easier to change the executive.

Table 3 Regression Analysis

\begin{tabular}{|l|l|l|l|}
\hline & Full sample & state-owned companies & non-state-owned companies \\
\hline constant & $-3.78^{* * *}$ & $-2.396^{* * *}$ & $-2.33^{*}$ \\
\hline ROA & $-3.34^{* *}$ & $-1.69^{*}$ & $-4.034^{* * *}$ \\
\hline size & $0.106^{* *}$ & 0.073 & 0.018 \\
\hline debt & -0.025 & $-0.6^{*}$ & -0.023 \\
\hline comp & -0.27 & -0.542 & -0.242 \\
\hline year & control & control & control \\
\hline industry & control & control & control \\
\hline
\end{tabular}

The significant levels are based on $* * * \mathrm{p}<1 \%$, ** $\mathrm{p}<5 \%, * \mathrm{p}<10 \%$. 


\section{Conclusions}

Through the data of listed companies in Chinese A stock market, this thesis empirically analyzes the impact of corporate performance on the executive turnover, and we can find through test results that:

(1) There is a significant negative correlation between corporate performance and executive turnover. The performance is not ideal is an important cause of executive turnover, and this also shows that governance mechanism of Chinese listed company is relatively effective, as it can replace incompetent executives in time.

(2) Compared with state-owned enterprises, the negative correlation between the two is stronger in private enterprises. Because the state-owned enterprises are often influenced by the policy, which means under the current economic environment, state-owned enterprises is not simply aim at the enterprise value maximization, they also have to take the social responsibility, government intervention is relatively stronger. Therefore non-state-owned enterprises are more conducive to the role of stakeholder governance.

According to the empirical results, we can find that corporate performance can supervise and restrain the executive behavior to a certain extent, but there are still some shortcomings. As excessive government intervention will cause economic disorder. And government have much stronger influence on state-owned enterprises rather than non-state-owned ones, which always leads to lower efficiency of corporate governance mechanism. Because of this, the relevant government departments need to adjust the enterprise management with market economy. What's more, marketization can enhance the negative correlation between corporate performance and executive turnover while government intervention can weaken the negative correlation, Chinese government needs to reduce excessive government intervention and give full play to the market. However, China's capital market development is not quite perfect presently, and in order to make the market play a better role of regulation, government should constantly improve the capital market, deepen the reform of market economy, deepen the process of marketization. At the same time, we need to improve the marketization degree of remote areas, reduce the gap between regional economic development and realize comprehensive marketization.

\section{References}

[1] Hu F, Leung S C M. Top management turnover, firm performance and government control: Evidence from China's listed state-owned enterprises $\_[\mathrm{J}]$. Social Science Electronic Publishing, 2012, 47(2):235-262.

[2] Ma Rujing, Tang Xuesong. Independent director of academic background, company performance and CEO change [J]. Financial science, 2016(9):77-87.63/5000

[3] Liu Qingsong, Xiao Xing. Empirical study on the change of senior executives of state-owned enterprises [J]. Management of the world, 2015(3):151-163.

[4] Wang Chengfang. Debt structure, enterprise performance and executive change [J]. Chinese CPA, 2014(8):35-41.

[5] Yao Zheng, Gu Huiying, Yan Qi. Research on the influence factors of risk enterprise executives in venture capital institutions [J]. Economic and management research, 2016, 37(7):135-144.

[6] Chen Lirong, Han Bin, Yang Xinglong. Research on the impact of corporate social responsibility and change of senior executives -- empirical evidence based on A-share listed companies [J]. Accounting research, 2015(8):57-64.

[7] Fan Gang, Wang Xiaolu, Zhu Hengpeng. China marketization index. The 2011 annual report [M]. Economic science press, 2011. 